\title{
Effect of Varying Dietary Ratios of Alfalfa Silage to Corn Silage on Production and Nitrogen Utilization in Lactating Dairy Cows ${ }^{1}$
}

\author{
A. F. Brito ${ }^{\star 2}$ and G. A. Broderick $\dagger^{3}$ \\ *Department of Dairy Science, University of Wisconsin, Madison 53706 \\ †USDA, ARS, US Dairy Forage Research Center, Madison 53706
}

duction. Because CS is complementary with AS, it is recommended that CS be fed in AS-based diets to maintain milk yield while improving $\mathrm{N}$ utilization.

Key words: production, nitrogen utilization, dairy cow

\section{INTRODUCTION}

Alfalfa silage (AS) is high in both CP and RDP and low in RUP. Corn silage (CS), because of its high starch content, is a good source of ruminally fermentable carbohydrates but is low in CP. Therefore, AS and CS are complementary forages. According to Dhiman and Satter (1997), AS and CS are also complementary for agronomic reasons: 1) both fit well into crop rotations for managing $\mathrm{N}$, and 2) each has a different harvest schedule, which reduces labor and equipment constraints.

Although not statistically significant, Dhiman and Satter (1997) reported 577 and $146 \mathrm{~kg}$ more milk over a 308-d lactation when feeding dietary forage as twothirds AS and one-third CS vs. feeding forage as, respectively, all AS or one-third AS and two-thirds CS. Apparent $\mathrm{N}$ efficiency tended to be higher when CS replaced AS in that trial; however, lower CP was fed in the diets containing CS. Although quite degradable, protein in solvent soybean meal (SSBM) is more resistant to ruminal degradation than that in AS (NRC, 2001) and will probably supply more RUP to the cow. Replacing AS with CP from CS plus SSBM likely will decrease ruminal ammonia and reduce urinary $\mathrm{N}$ excretion and $\mathrm{N}$ losses to the environment. Previously, Brito (2004) found that cows fed AS diets with higher NPN excreted more $\mathrm{N}$ in urine than cows fed red clover silage (RCS) diets with lower NPN. However, Ruppert et al. (2003) and Santos (2003) observed similar urinary N excretion when feeding high-AS or high-CS diets to lactating dairy cows. Ruppert et al. (2003) also reported greater $\mathrm{N}$ retention and productive $\mathrm{N}$ on high-AS vs. high-CS diets. Hence, more research is necessary to better understand the influence on $\mathrm{N}$ metabolism of feeding dairy cows different ratios of AS to CS.

The objectives of this study were to evaluate the effects of feeding different dietary ratios of AS to CS on production, $\mathrm{N}$ utilization, and ruminal metabolism in 
lactating dairy cows. Identifying the AS:CS ratio at which production was optimized at minimal $\mathrm{N}$ excretion was of particular interest in this work. It is important to emphasize that when AS was replaced with CS, SSBM was increased and rolled high-moisture shelled corn (HMSC) was decreased in an attempt to maintain isonitrogenous diets. Moreover, according to the NRC (2001) model, incremental amounts of CS plus SSBM will decrease the RDP supply and increase RUP flow.

\section{MATERIALS AND METHODS}

\section{Animals}

Twenty-eight (8 ruminally cannulated) multiparous Holstein cows, averaging $93(\mathrm{SD} \pm 45) \mathrm{DIM}$ and 644 $(\mathrm{SD} \pm 55) \mathrm{kg}$ of $\mathrm{BW}$ at the beginning of the trial, were blocked by DIM and randomly assigned within blocks to treatment sequences in 7 replicated $4 \times 4$ Latin squares (2 squares of ruminally cannulated cows). Treatment sequences within each square were balanced for carryover effects (i.e., each treatment followed each of the others once within each square). Each experimental period lasted $28 \mathrm{~d}$ and consisted of $14 \mathrm{~d}$ for adaptation and $14 \mathrm{~d}$ for sample and data collection. All cows were injected with bST (500 mg of Posilac; Monsanto, St. Louis, MO) beginning on $d 1$ of the trial and at 14$d$ intervals during the study. Cows were housed in tie stalls and had free access to water throughout the experiment. Care and handling of the animals, including ruminal cannulation, were conducted as outlined in the guidelines of the University of Wisconsin institutional animal care and use committee. One cow was removed from the trial at the beginning of the third period because of very low DMI. Therefore, production data were analyzed with 2 missing values.

\section{Diets}

Table 1 shows the chemical composition of the silages and concentrates used in this trial. Treatments were fed as TMR and contained (percentage of DM) the following proportions of AS:CS (Table 2): 51:0 (diet A), 37:13 (diet B), 24:27 (diet C), and 10:40 (diet D). Concentrate comprised approximately $50 \%$ of the diet DM and all diets were supplemented with $2 \%$ fat (Energy Booster; Milk Specialties Company, Dundee, IL) to provide extra energy. Diets were formulated to contain equal CP based on the initial composition of feed ingredients; however, AS increased from 21.7 to $24.3 \%$ CP over the course of the trial. Thus, dietary CP decreased by 1 percentage unit from the highest to lowest AS content (Table 2). Diets were offered once daily at $1000 \mathrm{~h}$. Orts were collected daily at $0900 \mathrm{~h}$ and the amount of feed offered
Table 1. Chemical composition of feed ingredients ${ }^{1}$

\begin{tabular}{lcccc}
\hline Item & AS & CS & HMSC & SSBM \\
\hline DM, \% & 40.6 & 45.0 & 72.6 & 90.1 \\
CP, \% of DM & 23.5 & 7.11 & 8.78 & 52.1 \\
Ash, \% of DM & 11.6 & 4.22 & 2.25 & 7.53 \\
Ammonia, \% of total N & 8.35 & 6.59 & - & - \\
Total free AA N, \% of total N & 27.7 & 22.3 & - & - \\
NPN, \% of total N & 48.0 & 29.9 & - & - \\
NDIN, \% of total N & 7.83 & 8.70 & 3.69 & 0.62 \\
ADIN, \% of total N & 3.62 & 2.17 & 0.61 & 0.23 \\
NDF, \% of DM & 38.1 & 41.1 & 8.70 & 7.89 \\
ADF, \% of DM & 29.6 & 21.9 & 2.19 & 4.75 \\
Hemicellulose, \% of DM & 8.54 & 19.1 & 6.51 & 3.14 \\
pH & 4.82 & 3.99 & - & - \\
\hline
\end{tabular}

${ }^{1} \mathrm{AS}=$ Alfalfa silage $; \mathrm{CS}=$ corn silage HMSC = rolled high-moisture shelled corn; SSBM = solvent soybean meal; NDIN = neutral detergent insoluble N; ADIN = acid detergent insoluble $\mathrm{N}$.

${ }^{2}$ Total free AA N = total free AA, mmol $\times(40.3 \mathrm{mg}$ of $\mathrm{N} / \mathrm{mmol}$ of total free AA) (Broderick, 1987).

to the cows was adjusted daily to yield refusals equal to approximately 5 to $10 \%$ of intake.

\section{Sampling and Laboratory Analyses}

Daily samples of approximately $0.5 \mathrm{~kg}$ of $\mathrm{AS}, \mathrm{CS}$, HMSC, TMR, and orts were collected, stored at $-20^{\circ} \mathrm{C}$, and used to make weekly composites; weekly samples of SSBM also were taken.

Dry matter contents of weekly composites of all feeds, TMR, and orts were determined by drying at $60^{\circ} \mathrm{C}$ (forced-air oven) for $48 \mathrm{~h}$. Dried samples were ground to pass a 1-mm screen (Wiley mill; Arthur H. Thomas, Philadelphia, PA) and analyzed for total N (Leco FP2000 nitrogen analyzer; Leco Instruments, Inc., St. Joseph, MI). Dry matter contents $\left(60^{\circ} \mathrm{C}\right.$ forced air-oven for $48 \mathrm{~h}$ ) from weekly composites of AS, CS, and HMSC and from a weekly sample of SSBM were used to adjust as-fed compositions of TMR. Period composites of the dietary ingredients and TMR were prepared by mixing equal amounts of DM from dried weekly subsamples from the last 2 wk of each period. Dry matter intakes were based on the $60^{\circ} \mathrm{C} \mathrm{DM}$ of TMR and orts.

Cows were milked twice daily and milk yield was recorded at each milking. Milk samples from a.m. and p.m. milkings were collected on d 19 and 26 of each period and analyzed for fat, true protein, lactose, and SNF by infrared analysis (AgSource, Verona, WI) with a Foss FT6000 instrument (Foss North America Inc., Eden Prairie, MN) using AOAC Method 972.16 (AOAC, 1990). Concentration and yield of milk components were computed as the weighted means from a.m. and p.m. milk yields on each test day. Milk samples were deproteinized (Shahani and Sommer, 1951) and stored at $-20^{\circ} \mathrm{C}$ until analyzed for MUN by an automated colorimetric assay (Broderick and Clayton, 1997) adapted 
Table 2. Composition of $\operatorname{diets}^{1}$

\begin{tabular}{|c|c|c|c|c|}
\hline \multirow[b]{2}{*}{ Item } & \multicolumn{4}{|c|}{ Diet (AS:CS) } \\
\hline & $\mathrm{A}(51: 0)$ & B $(37: 13)$ & $\mathrm{C}(24: 27)$ & $\mathrm{D}(10: 40)$ \\
\hline \multicolumn{5}{|l|}{ Ingredient } \\
\hline AS & 50.6 & 37.2 & 23.7 & 10.2 \\
\hline $\mathrm{CS}$ & - & 13.3 & 26.7 & 40.0 \\
\hline Rolled HMSC & 43.3 & 39.1 & 34.7 & 30.5 \\
\hline SSBM & 2.95 & 7.25 & 11.7 & 16.1 \\
\hline Energy booster ${ }^{2}$ & 1.98 & 1.99 & 1.99 & 1.99 \\
\hline Sodium bicarbonate & 0.74 & 0.74 & 0.74 & 0.74 \\
\hline Salt & 0.20 & 0.20 & 0.20 & 0.20 \\
\hline Dicalcium phosphate & 0.20 & 0.20 & 0.20 & 0.20 \\
\hline Vitamin and trace mineral premix ${ }^{3}$ & 0.10 & 0.10 & 0.10 & 0.10 \\
\hline \multicolumn{5}{|l|}{ Chemical composition } \\
\hline $\mathrm{DM}, \%$ & 52.5 & 53.7 & 55.1 & 56.5 \\
\hline $\mathrm{CP}, \%$ of $\mathrm{DM}$ & 17.2 & 16.9 & 16.6 & 16.2 \\
\hline Ash, \% of DM & 8.32 & 7.57 & 6.82 & 6.06 \\
\hline $\mathrm{NDF}, \%$ of $\mathrm{DM}$ & 23.3 & 23.5 & 23.8 & 24.1 \\
\hline $\mathrm{ADF}, \%$ of $\mathrm{DM}$ & 16.1 & 15.1 & 14.1 & 13.1 \\
\hline NDIN, \% of total $\mathrm{N}$ & 6.25 & 5.39 & 4.48 & 3.55 \\
\hline ADIN, \% of total $\mathrm{N}$ & 2.60 & 2.13 & 1.62 & 1.11 \\
\hline RDP estimated, ${ }^{4} \%$ of DM & 12.9 & 11.9 & 11.0 & 10.2 \\
\hline RUP estimated, ${ }^{4} \%$ of DM & 4.36 & 5.03 & 5.60 & 6.08 \\
\hline RDP measured, ${ }^{5} \%$ of DM & $11.7^{\mathrm{a}}$ & $11.4^{\mathrm{a}}$ & $10.5^{\mathrm{b}}$ & $10.1^{\mathrm{b}}$ \\
\hline RUP measured, ${ }^{5} \%$ of DM & 5.59 & 5.52 & 6.09 & 6.13 \\
\hline $\mathrm{MP},{ }^{4} \mathrm{~g} / \mathrm{kg} \mathrm{DM}$ & 94.4 & 101 & 106 & 111 \\
\hline Metabolizable Lys, ${ }^{4} \mathrm{~g} / \mathrm{kg}$ DM & 6.22 & 6.53 & 6.82 & 7.15 \\
\hline Metabolizable Met, ${ }^{4} \mathrm{~g} / \mathrm{kg}$ DM & 1.85 & 1.89 & 1.94 & 2.01 \\
\hline Lys:Met ratio 4 & 3.37 & 3.46 & 3.52 & 3.55 \\
\hline $\mathrm{NFC},{ }^{6} \%$ of $\mathrm{DM}$ & 48.3 & 48.7 & 49.2 & 49.8 \\
\hline $\mathrm{NE}_{\mathrm{L}},{ }^{7} \mathrm{Mcal} / \mathrm{kg}$ of $\mathrm{DM}$ & 1.62 & 1.60 & 1.61 & 1.65 \\
\hline
\end{tabular}

\footnotetext{
${ }^{\mathrm{a}, \mathrm{b}}$ Means with different superscripts differ $(P<0.01)$

${ }^{1} \mathrm{AS}=$ Alfalfa silage CS = corn silage HMSC = high-moisture shelled corn; $\mathrm{SSBM}$ = solvent soybean meal; NDIN = neutral detergent insoluble $\mathrm{N}$.

${ }^{2}$ Energy Booster 100, Milk Specialties Company (Dundee, IL).

${ }^{3}$ Provided (per kilogram of DM): $56 \mathrm{mg}$ of $\mathrm{Zn}, 46 \mathrm{mg}$ of $\mathrm{Mn}, 22 \mathrm{mg}$ of Fe, $12 \mathrm{mg}$ of Cu, $0.9 \mathrm{mg}$ of I, 0.4 $\mathrm{mg}$ of Co, $0.3 \mathrm{mg}$ of Se, 6,440 IU of vitamin A, 2,000 IU of vitamin D, and $16 \mathrm{IU}$ of vitamin E.

${ }^{4}$ Estimated by the NRC (2001) model.

${ }^{5}$ Measured in vivo (Brito et al., 2006).

${ }^{6} \mathrm{NFC}=100-(\% \mathrm{NDF}+\% \mathrm{CP}+\%$ fat $+\%$ ash $)$ according to the NRC (2001) model.

${ }^{7}$ Computed by discounting dietary energy content based on actual DMI (NRC, 2001).
}

to flow-injection analysis (Lachat Quik-Chem 8000 FIA; Lachat Instruments, Milwaukee, WI). Concentrations of MUN were computed as the weighted means from a.m. and p.m. milk yields on each test day. Supernatants from deproteinized milk also were analyzed for NPN using a combustion assay (Mitsubishi TN-05 nitrogen analyzer; Mitsubishi Chemical Corp., Tokyo, Japan). Feed efficiency was computed for each cow by dividing mean milk yield by mean DMI over the last 2 wk of each period. Apparent efficiency of utilization of feed $\mathrm{N}$ (assuming no retention or mobilization of body $\mathrm{N})$ was calculated for each cow by dividing mean milk $\mathrm{N}$ output (total milk protein/6.38) by mean $\mathrm{N}$ intake. Body weights were measured on 3 consecutive days at the beginning of the experiment and at the end of each period to compute BW change.

Samples of whole ruminal contents (about $200 \mathrm{~mL}$ ) were taken from the ventral sac of the rumen of the 8 ruminally cannulated cows at 0 (prefeeding), $1,2,4,8$, 12,18 , and $24 \mathrm{~h}$ postfeeding on d 21 to 22 of each period, then strained through 2 layers of cheesecloth, followed immediately by $\mathrm{pH}$ measurement. Two $10-\mathrm{mL}$ samples were then preserved by addition of $0.2 \mathrm{~mL}$ of $50 \% \mathrm{H}_{2} \mathrm{SO}_{4}$ and stored at $-20^{\circ} \mathrm{C}$ until analysis. Samples were thawed at room temperature, centrifuged $(15,000 \times g$, $15 \mathrm{~min}, 4^{\circ} \mathrm{C}$ ), and the supernatants analyzed for ammonia and total free AA (Broderick and Kang, 1980) using flow-injection (Lachat Quik-Chem 8000 FIA) and for VFA using gas chromatography (Brotz and Schaefer, 1987).

Spot urine samples were obtained approximately 6 $\mathrm{h}$ prefeeding and $6 \mathrm{~h}$ postfeeding on $\mathrm{d} 20$ of each period through mechanical stimulation of the vulva. After collection, $15 \mathrm{~mL}$ of urine was pipeted into a specimen container containing $60 \mathrm{~mL}$ of $0.072 \mathrm{~N} \mathrm{H}_{2} \mathrm{SO}_{4}$ and stored at $-20^{\circ} \mathrm{C}$ until analyzed. After thawing at room 
temperature, urine samples were analyzed for creatinine, using a picric acid assay (Oser, 1965) adapted to flow injection (Lachat Quik-Chem 8000 FIA); total N (Mitsubishi TN-05 nitrogen analyzer); allantoin, using the method of Vogels and van der Grift (1970) adapted to a 96-well plate reader; and urea, with the colorimetric method also used for MUN. Daily urinary volume and excretion of urea $\mathrm{N}$, total $\mathrm{N}$, and allantoin were estimated from urinary creatinine concentration assuming a creatinine excretion rate of $29 \mathrm{mg} / \mathrm{kg}$ of BW (Valadares et al., 1999). Fecal grab samples were collected at the time of urine sampling, transferred to aluminum pans, and placed in a forced-air oven at $60^{\circ} \mathrm{C}$ until completely dry. Fecal samples were then ground to pass a 1-mm Wiley mill screen and composites were prepared by mixing equal amounts of DM from both samples. Fecal samples were analyzed for total $\mathrm{N}$ using a combustion assay (Leco FP-2000 nitrogen analyzer), sequentially for NDF and ADF using heat-stable $\alpha$-amylase and $\mathrm{Na}_{2} \mathrm{SO}_{3}$ (Hintz et al., 1995), and for indigestible ADF (ADF remaining after $12 \mathrm{~d}$ of in situ incubation; Huhtanen et al., 1994). Indigestible ADF was used as an internal marker to estimate apparent nutrient digestibility and fecal output (Cochran et al., 1986).

Blood samples were collected into heparinized tubes from the coccygeal artery or vein of each cow $4 \mathrm{~h}$ after feeding on $\mathrm{d} 19$ of each period and stored at $-20^{\circ} \mathrm{C}$ until analyzed. After thawing at room temperature, $5 \mathrm{~mL}$ of heparinized blood was transferred to a $15-\mathrm{mL}$ centrifuge tube. Then $1.25 \mathrm{~mL}$ of $25 \% \mathrm{TCA}$ (wt/vol) was added to each tube; the tubes were vortexed, allowed to stand for $30 \mathrm{~min}$ at room temperature, centrifuged $(15,000 \times$ $\mathrm{g}, 15 \mathrm{~min}, 4^{\circ} \mathrm{C}$ ), and the supernatants stored at $-20^{\circ} \mathrm{C}$ until thawed and analyzed for BUN using the colorimetric method also used for MUN.

The composites from weeks 3 to 4 of TMR and feed ingredients were analyzed for total N (Leco FP-2000 nitrogen analyzer), absolute $\mathrm{DM}\left(105^{\circ} \mathrm{C}\right)$, ash and $\mathrm{OM}$ (AOAC, 1980); analyzed sequentially for NDF and ADF using heat-stable $\alpha$-amylase and $\mathrm{Na}_{2} \mathrm{SO}_{3}$ (Hintz et al., 1995); and analyzed for neutral detergent insoluble $\mathrm{N}$ (NDIN) and ADIN. These TMR samples also were analyzed for indigestible $\mathrm{ADF}$ as described earlier for fecal composites. Silage extracts were prepared from weekly composites as described by Muck (1987) and $\mathrm{pH}$ was determined immediately. Extracts were deproteinized and analyzed for NPN (Muck, 1987) using the combustion assay (Mitsubishi TN-05 nitrogen analyzer) and for ammonia and total free AA using the same approach as for strained ruminal fluid.

\section{Statistical Analysis}

Data were analyzed using the mixed procedures of SAS (SAS Institute, 1999-2000) for a replicated $4 \times 4$
Latin square design. The following model was fit for all variables not having repeated measures over time:

$$
\mathrm{Y}_{\mathrm{ijkl}}=\mu+\mathrm{S}_{\mathrm{i}}+\mathrm{P}_{\mathrm{j}}+\mathrm{C}_{\mathrm{k}(\mathrm{i})}+\mathrm{T}_{\mathrm{l}}+\mathrm{ST}_{\mathrm{il}}+\mathrm{E}_{\mathrm{ijkl}}
$$

where $Y_{i j k l}$ is the dependent variable, $\mu$ is the overall mean, $S_{i}$ is the effect of square $i, P_{j}$ is the effect of period $\mathrm{j}, \mathrm{C}_{\mathrm{k}(\mathrm{i})}$ is the effect of cow $\mathrm{k}$ (within square $\mathrm{i}$ ), $\mathrm{T}_{1}$ is the effect of treatment $1, \mathrm{ST}_{\mathrm{il}}$ is the interaction between square $\mathrm{i}$ and treatment $\mathrm{l}$, and $\mathrm{E}_{\mathrm{ijkl}}$ is the residual error. All terms were considered fixed except $\mathrm{C}_{\mathrm{k}(\mathrm{i})}$ and $\mathrm{E}_{\mathrm{ijk} \mathrm{k}}$, which were considered random. The interaction term was removed from the model when $P>0.25$. Significance was declared at $P \leq 0.05$ and trends at $0.05<P$ $\leq 0.10$. All reported values are least squares means, which were separated using the PDIFF test in SAS. Because proportions of AS and CS among treatments were not equally spaced, linear and quadratic effects of the AS:CS ratio were tested by partitioning the degrees of freedom for diet into single degrees of freedom corresponding to linear, quadratic, and cubic effects. The polynomial regression model included square, period, and linear effects of forage; a quadratic effect of forage; and a cubic effect of forage. Forage was used to indicate either the decreasing levels of AS or the increasing levels of CS in the diet. Cubic effects were not statistically significant $(P \geq 0.10)$ for any variable and are not reported.

Ruminal $\mathrm{pH}$ values were more normally distributed than were hydrogen ion concentrations; thus, only ruminal $\mathrm{pH}$ data were statistically analyzed. The following model was adopted for ruminal $\mathrm{pH}$, ammonia, total free AA, and VFA, which had repeated measures over time:

$$
\begin{aligned}
\mathrm{Y}_{\mathrm{ijkl}}=\mu+ & \mathrm{S}_{\mathrm{i}}+\mathrm{P}_{\mathrm{j}}+\mathrm{C}_{\mathrm{k}(\mathrm{i})}+\mathrm{T}_{\mathrm{l}}+\mathrm{S} \mathrm{T}_{\mathrm{il}}+\mathrm{E} 1_{\mathrm{ijkl}} \\
& +\mathrm{H}_{\mathrm{m}}+\mathrm{HT}_{\mathrm{ml}}+\mathrm{E} 2_{\mathrm{ijklm}}
\end{aligned}
$$

where $Y_{i j k l}$ is the dependent variable, $\mu$ is the overall mean, $S_{i}$ is the effect of square $i, P_{j}$ is the effect of period $\mathrm{j}, \mathrm{C}_{\mathrm{k}(\mathrm{i})}$ is the effect of cow $\mathrm{k}$ (within square $\mathrm{i}$ ), $\mathrm{T}_{\mathrm{l}}$ is the effect of treatment $1, \mathrm{ST}_{\mathrm{il}}$ is the interaction between square $\mathrm{i}$ and treatment $\mathrm{l}, \mathrm{E} 1_{\mathrm{ijk}}$ is whole plot error, $\mathrm{H}_{\mathrm{m}}$ is the effect of hours postfeeding analyzed as repeated measurements, $\mathrm{HT}_{\mathrm{ml}}$ is the interaction between hour $\mathrm{m}$ and treatment 1 , and $\mathrm{E} 2_{\mathrm{ijklm}}$ is the subplot error. The spatial covariance structure $\mathrm{SP}(\mathrm{POW})$ was used for estimating covariances, and the subject of the repeated measurements was defined as cow(square $x$ period $x$ treatment). All terms were considered fixed except $\mathrm{C}_{\mathrm{k}(\mathrm{i})}$, $\mathrm{E} 1_{\mathrm{ijk}}$, and $\mathrm{E} 2_{\mathrm{ijklm}}$, which were considered random. The interaction term was removed from the model when $P$ $>0.25$. Significance was declared at $P \leq 0.05$ and trends 
at $0.05<P \leq 0.10$. All reported values are least squares means, which were separated using the PDIFF test in SAS. Because proportions of AS and CS among treatments were not equally spaced, linear and quadratic effects of the AS:CS ratio were tested by partitioning the degrees of freedom for diet into single degrees of freedom corresponding to linear, quadratic, and cubic effects. The polynomial regression model included square, period, time, linear effect of forage, quadratic effect of forage, cubic effect of forage, and the interactions time $\times$ linear effect of forage, time $\times$ quadratic effect of forage, and time $\times$ cubic effect of forage. Forage was used to indicate either the decreasing levels of AS or the increasing levels of CS. Cubic effects were not statistically significant $(P \geq 0.10)$ for any variable and are therefore not reported.

\section{RESULTS AND DISCUSSION}

\section{Forage and Diet Composition}

Chemical compositions of feeds fed in this trial are shown in Table 1. Crude protein content of AS and CS averaged 23.5 and $7.1 \%$, which were similar to values reported in the literature for these forages. Neutral detergent fiber and ADF contents of both also were typical of high-quality forages. The $\mathrm{CP}$, ash, NDF, and ADF contents of HMSC and SSBM also were within the expected ranges. Ammonia N, free AA N, and total NPN, as proportions of total N, were typical for the 2 silages (Muck et al., 1996) and indicated that CS contributed much less NPN to the ration than AS. A greater buffering capacity in AS relative to CS (Van Soest et al., 1991) probably accounted for the higher mean $\mathrm{pH}$ of AS extracts compared with CS extracts (Table 1).

Dietary SSBM was increased from 3.0 (diet A) to $16.1 \%$ of DM (diet D) to maintain CP levels as CS replaced AS and HMSC. However, actual dietary CP contents declined from diet $\mathrm{A}$ to $\operatorname{diet} \mathrm{D}$ (Table 2) because the CP content of AS increased from 21.7 to $24.3 \%$ over the course of the trial, and diets did not remain isonitrogenous as formulated. Ash and ADF contents of the diets also decreased (Table 2) from, respectively, $8.32(\operatorname{diet} \mathrm{A})$ to $6.06 \%$ of $\mathrm{DM}(\operatorname{diet} \mathrm{D})$ and from 16.1 (diet A) to $13.1 \%$ of $\mathrm{DM}$ (diet D), reflecting the higher ash and ADF levels in AS (Table 1). On the other hand, NDF increased slightly from $\operatorname{diet} A$ to $\operatorname{diet} \mathrm{D}$ (Table 2) as a result of the higher NDF content of CS (Table 1). Neutral detergent insoluble nitrogen and ADIN were, respectively, 43 and $57 \%$ higher on diet A compared with diet D (Table 2) because of the greater NDIN and ADIN in HMSC vs. SSBM (Table 1). Energy and NFC contents computed from the NRC (2001) were similar among diets (Table 2).

\section{Animal Production}

Treatment effects on DMI, milk yield, and milk composition are shown in Table 3. Intake of DM decreased linearly $(P<0.01)$ from that on the diet with forage solely from AS to that on the diet with most of the forage coming from CS. A quadratic effect $(P=0.04)$ with maximum at $51 \%$ dietary AS (Table 4 ) also was observed. Onetti et al. (2002) and Moreira et al. (V. R. Moreira, C. Cragnolino, and L. D. Satter, Univ. Wisc.; unpublished manuscript) both observed linear $(P<$ 0.01) increases in DMI as AS plus HMSC replaced CS plus SSBM in the diet. Furthermore, Ruppert et al. (2003) demonstrated that cows fed a high-AS diet had greater DMI $(P<0.01)$ than those fed a high-CS diet. Onetti et al. (2002) speculated that increased DMI might have been a consequence of higher NDF digestibility for AS compared with CS. In fact, Oba and Allen (1999) reported that enhanced NDF digestibility increased DMI. The $12 \%$ reduction in DMI from diet A to diet $\mathrm{D}$ was probably related to depressed ruminal fiber digestibility resulting from the effects of greater starch intake, lower ruminal $\mathrm{pH}$, and inhibition of cellulolytic bacteria and will be discussed later in greater detail.

Milk yield decreased linearly $(P=0.02)$ as CS plus SSBM replaced AS plus HMSC, but no difference in milk production was observed among cows fed diets A, $\mathrm{B}$, or $\mathrm{C}$ (Table 3). However, cows fed diet $\mathrm{D}$, with the highest proportion of CS, yielded at least $2.0 \mathrm{~kg} / \mathrm{d}$ less milk $(P=0.03)$ than those fed diets with lower CS. Yield of 3.5\% FCM also declined linearly $(P<0.01)$; a large difference of $4.6 \mathrm{~kg} / \mathrm{d}$ of $3.5 \% \mathrm{FCM}$ was observed between cows fed $\operatorname{diet} \mathrm{A}$ and those fed $\operatorname{diet} \mathrm{D}$, whereas cows fed diets $\mathrm{B}$ and $\mathrm{C}$ were intermediate. In the study by Moreira et al. (V. R. Moreira, C. Cragnolino, and L. D. Satter, unpublished manuscript), cows fed $100 \%$ CS yielded 3.5 and $2.6 \mathrm{~kg} / \mathrm{d}$ less FCM than those fed diets with $75 \%$ CS and 25\% AS and with 50\% CS and 50\% AS, respectively. The linear reduction in milk yield in the current trial paralleled the decrease in DMI from $\operatorname{diet} \mathrm{A}$ to D, suggesting that lower DMI accounted for the depressed milk production. Moreover, a 27\% decrease in intake of digestible NDF occurred between $\operatorname{diet} \mathrm{A}(2.43$ $\mathrm{kg} / \mathrm{d})$ and diet $\mathrm{D}(1.78 \mathrm{~kg} / \mathrm{d})$, so the reduction in milk yield can be explained by lower nutrient availability to the animal. Also, a quadratic effect was found for milk yield $(P=0.04)$, with maximum at $37 \%$ AS (Table 4$)$, indicating that, for maximal milk production, it was unnecessary to feed high levels of CS.

Broderick (1985), in one of 2 trials, reported no difference in milk yield when cows were fed diets containing $60 \%$ of DM as AS or CS as the sole forage. When CS was increased from 60 to $79 \%$ of DM, milk yield was 
Table 3. Effects of varying dietary ratios of alfalfa silage (AS) to corn silage (CS) on the production of lactating dairy cows

\begin{tabular}{|c|c|c|c|c|c|c|c|c|}
\hline \multirow[b]{2}{*}{ Item } & \multicolumn{4}{|c|}{ Diet (AS:CS) } & \multirow[b]{2}{*}{$\mathrm{SED}^{1}$} & \multicolumn{3}{|c|}{ Significance $^{2}(P$-value $)$} \\
\hline & A (51:0) & В $(37: 13)$ & C $(24: 27)$ & $\mathrm{D}(10: 40)$ & & Diet & $\mathrm{L}$ & $\mathrm{Q}$ \\
\hline DMI, kg/d & $26.8^{\mathrm{a}}$ & $26.5^{\mathrm{a}}$ & $25.4^{\mathrm{b}}$ & $23.7^{\mathrm{c}}$ & 0.44 & $<0.01$ & $<0.01$ & 0.04 \\
\hline $\mathrm{N}$ intake, $\mathrm{g} / \mathrm{d}$ & $744^{\mathrm{a}}$ & $719^{\mathrm{b}}$ & $675^{\mathrm{c}}$ & $617^{\mathrm{d}}$ & 12.3 & $<0.01$ & $<0.01$ & 0.06 \\
\hline NDF intake, $\mathrm{kg} / \mathrm{d}$ & $6.25^{\mathrm{a}}$ & $6.22^{\mathrm{ab}}$ & $6.03^{\mathrm{b}}$ & $5.71^{\mathrm{c}}$ & 0.11 & $<0.01$ & $<0.01$ & 0.07 \\
\hline ADF intake, $\mathrm{kg} / \mathrm{d}$ & $4.33^{\mathrm{a}}$ & $4.00^{\mathrm{b}}$ & $3.58^{\mathrm{c}}$ & $3.12^{\mathrm{d}}$ & 0.73 & $<0.01$ & $<0.01$ & NS \\
\hline Milk yield, kg/d & $41.5^{\mathrm{a}}$ & $42.0^{\mathrm{a}}$ & $41.5^{\mathrm{a}}$ & $39.5^{\mathrm{b}}$ & 0.86 & 0.03 & 0.02 & 0.04 \\
\hline $3.5 \% \mathrm{FCM}, \mathrm{kg} / \mathrm{d}$ & $43.3^{\mathrm{a}}$ & $42.7^{\mathrm{ab}}$ & $40.5^{\mathrm{bc}}$ & $38.7^{\mathrm{c}}$ & 1.29 & $<0.01$ & $<0.01$ & NS \\
\hline Milk fat, \% & $3.81^{\mathrm{a}}$ & $3.58^{\mathrm{ab}}$ & $3.38^{\mathrm{bc}}$ & $3.34^{\mathrm{c}}$ & 0.12 & $<0.01$ & $<0.01$ & NS \\
\hline Milk fat, $\mathrm{kg} / \mathrm{d}$ & $1.56^{\mathrm{a}}$ & $1.51^{\mathrm{ab}}$ & $1.40^{\mathrm{bc}}$ & $1.33^{\mathrm{c}}$ & 0.06 & $<0.01$ & $<0.01$ & NS \\
\hline Milk protein, $\%$ & $3.07^{\mathrm{b}}$ & $3.13^{\mathrm{ab}}$ & $3.14^{\mathrm{ab}}$ & $3.17^{\mathrm{a}}$ & 0.04 & 0.05 & $<0.01$ & NS \\
\hline Milk protein, $\mathrm{kg} / \mathrm{d}$ & 1.26 & 1.32 & 1.30 & 1.25 & 0.03 & 0.13 & 0.72 & 0.02 \\
\hline Lactose, $\%$ & 4.88 & 4.85 & 4.83 & 4.84 & 0.03 & 0.32 & 0.12 & NS \\
\hline $\mathrm{kg} / \mathrm{d}$ & 2.02 & 2.06 & 2.02 & 1.93 & 0.06 & 0.11 & 0.07 & 0.10 \\
\hline $\mathrm{SNF}, \%$ & 8.88 & 8.90 & 8.89 & 8.94 & 0.05 & 0.53 & 0.21 & NS \\
\hline $\mathrm{SNF}, \mathrm{kg} / \mathrm{d}$ & 3.66 & 3.77 & 3.70 & 3.55 & 0.09 & 0.13 & 0.18 & 0.05 \\
\hline Milk yield:DMI & $1.53^{\mathrm{b}}$ & $1.58^{\mathrm{b}}$ & $1.64^{\mathrm{a}}$ & $1.67^{\mathrm{a}}$ & 0.03 & $<0.01$ & $<0.01$ & NS \\
\hline 3.5\% FCM:DMI & 1.60 & 1.60 & 1.58 & 1.61 & 0.04 & 0.87 & 0.72 & NS \\
\hline Milk NPN, mg/dL & $33.6^{\mathrm{ab}}$ & $32.5^{\mathrm{b}}$ & $32.5^{\mathrm{b}}$ & $33.8^{\mathrm{a}}$ & 0.61 & 0.04 & 0.88 & $<0.01$ \\
\hline MUN, mg/dL & 13.8 & 13.9 & 14.1 & 14.4 & 0.47 & 0.60 & 0.17 & NS \\
\hline MUN, $\%$ of milk NPN & 41.3 & 43.2 & 44.0 & 42.5 & 1.78 & 0.47 & 0.40 & NS \\
\hline BUN, mg/dL & $18.4^{\mathrm{ab}}$ & $17.1^{\mathrm{b}}$ & $18.6^{\mathrm{a}}$ & $19.0^{\mathrm{a}}$ & 0.72 & 0.05 & 0.17 & 0.10 \\
\hline BW change, $\mathrm{kg} / \mathrm{d}$ & 0.92 & 0.90 & 1.08 & 1.03 & 0.19 & 0.71 & 0.37 & NS \\
\hline
\end{tabular}

${ }^{\mathrm{a}-\mathrm{d}}$ Means in the same row with different superscripts differ $(P \leq 0.05)$.

${ }^{1} \mathrm{SED}=$ Standard error of the least squares means difference.

${ }^{2} \mathrm{~L}=$ Linear effect; $\mathrm{Q}=$ quadratic effect; $\mathrm{NS}=$ not significant.

reduced $(P<0.05)$ from 26.1 to $23.9 \mathrm{~kg} / \mathrm{d}$. In a second study, milk yield was significantly reduced from 30.3 to $28 \mathrm{~kg} / \mathrm{d}$ when CS was increased from 60 to $76 \%$ of DM. Conversely, Wattiaux and Karg (2004a) fed lactating dairy cows dietary forage (DM basis) as $14 \% \mathrm{AS}$ plus $41 \% \mathrm{CS}$ or $14 \%$ CS plus $41 \% \mathrm{AS}$ and observed greater milk yield on the higher CS diets $(49.0 \mathrm{~kg} / \mathrm{d})$ than on the higher AS diets $(46.4 \mathrm{~kg} / \mathrm{d})$. However, fat yield was depressed on the CS diets and production of $3.5 \%$ FCM was similar on diets containing CS (45.9 $\mathrm{kg} / \mathrm{d}$ ) and AS (46.2 kg/d) (Wattiaux and Karg, 2004a). Several other authors (Onetti et al., 2002; Krause and
Combs, 2003; Ruppert et al., 2003) reported similar milk yields when different dietary ratios of AS:CS were fed. In the trials of Onetti et al. (2002) and Ruppert et al. (2003), DMI increased significantly for cows fed diets with higher proportions of AS, but higher DMI did not improve milk yield. Onetti et al. (2002) hypothesized that greater DMI reduced ruminal retention time and, consequently, decreased differences in energy available for milk yield among treatments. Despite differences in composition and digestibility between AS and CS, cows fed diets containing various ratios of AS:CS may be expected to have similar milk yields if the supply of

Table 4. Regression coefficients and quadratic maxima and minima of dietary alfalfa silage (AS) for variables with significant quadratic effects

\begin{tabular}{|c|c|c|c|c|c|c|c|}
\hline Item & Intercept & $\mathrm{SE}$ & $\begin{array}{l}\text { Linear } \\
\text { coefficient }\end{array}$ & $\mathrm{SE}$ & $\begin{array}{l}\text { Quadratic } \\
\text { coefficient }\end{array}$ & $\mathrm{SE}$ & $\begin{array}{l}\text { Quadratic } \\
\text { maxima/minima } \\
(\mathrm{AS}, \% \text { of } \mathrm{DM})\end{array}$ \\
\hline DMI, kg/d & 19.4 & 1.54 & 0.184 & 0.05 & -0.0018 & 0.0008 & 51 \\
\hline Milk yield, kg/d & 24.1 & 2.63 & 0.259 & 0.10 & -0.0035 & 0.002 & 37 \\
\hline Milk protein yield, kg/d & 0.97 & 0.09 & 0.009 & 0.004 & -0.0001 & 0.00006 & 31 \\
\hline SNF yield, kg/d & 2.42 & 0.26 & 0.025 & 0.01 & -0.0004 & 0.00018 & 35 \\
\hline Milk NPN, mg/dL & 33.6 & 1.71 & -0.212 & 0.08 & 0.0035 & 0.001 & 31 \\
\hline Total tract NDF digestibility, \% & 26.2 & 2.31 & 0.459 & 0.13 & -0.0046 & 0.002 & 50 \\
\hline Total tract ADF digestibility, \% & 29.0 & 1.97 & 0.606 & 0.11 & -0.0069 & 0.002 & 44 \\
\hline Urinary urea, $\%$ of total $\mathrm{N}$ & 99.1 & 4.88 & -0.964 & 0.30 & 0.0159 & 0.005 & 30 \\
\hline Urinary urea, $\%$ of $\mathrm{N}$ intake & 35.9 & 2.72 & -0.309 & 0.14 & 0.0047 & 0.0023 & 30 \\
\hline Ruminal valerate, $\mathrm{m} M$ & 3.06 & 0.46 & -0.092 & 0.03 & 0.0013 & 0.0004 & 35 \\
\hline
\end{tabular}

${ }^{1}[$-linear coefficient $\div(2 \times$ quadratic coefficient $)]$. 
Table 5. Effects of varying dietary ratios of alfalfa silage (AS) to corn silage (CS) on total tract apparent digestibility and ruminal metabolism in lactating dairy cows

\begin{tabular}{|c|c|c|c|c|c|c|c|c|}
\hline \multirow[b]{2}{*}{ Item } & \multicolumn{4}{|c|}{ Diet (AS:CS) } & \multirow[b]{2}{*}{$\mathrm{SED}^{1}$} & \multicolumn{3}{|c|}{ Significance $^{2}(P$-value $)$} \\
\hline & $\mathrm{A}(51: 0)$ & B $(37: 13)$ & C $(24: 27)$ & $\mathrm{D}(10: 40)$ & & Diet & $\mathrm{L}$ & $\mathrm{Q}$ \\
\hline \multicolumn{9}{|l|}{ Apparent digestibility } \\
\hline DM, \% & 65.2 & 65.5 & 67.0 & 65.8 & 0.82 & 0.14 & 0.21 & NS \\
\hline $\mathrm{OM}, \%$ & 65.8 & 66.2 & 67.7 & 66.9 & 0.84 & 0.13 & 0.08 & NS \\
\hline $\mathrm{NDF}, \%$ & $38.9^{\mathrm{a}}$ & $37.2^{\mathrm{ab}}$ & $36.1^{b}$ & $31.2^{\mathrm{c}}$ & 1.10 & $<0.01$ & $<0.01$ & 0.04 \\
\hline $\mathrm{ADF}, \%$ & $41.3^{\mathrm{a}}$ & $40.9^{\mathrm{a}}$ & $38.8^{\mathrm{b}}$ & $33.5^{\mathrm{c}}$ & 0.91 & $<0.01$ & $<0.01$ & $<0.01$ \\
\hline Hemicellulose, \% & 23.7 & 22.1 & 25.3 & 22.2 & 1.67 & 0.20 & 0.91 & NS \\
\hline $\mathrm{CP}, \%$ & $63.0^{\mathrm{b}}$ & $63.6^{\mathrm{b}}$ & $66.2^{\mathrm{a}}$ & $66.0^{\mathrm{a}}$ & 1.20 & 0.01 & $<0.01$ & NS \\
\hline \multicolumn{9}{|l|}{ Ruminal metabolism } \\
\hline $\mathrm{pH}$ & 6.29 & 6.31 & 6.30 & 6.31 & 0.05 & 0.99 & 0.77 & NS \\
\hline Ammonia $\mathrm{N}, \mathrm{mg} / \mathrm{dL}$ & $10.5^{\mathrm{a}}$ & $10.0^{\mathrm{ab}}$ & $8.72^{b}$ & $6.19^{c}$ & 0.92 & $<0.01$ & $<0.01$ & NS \\
\hline Total free AA, $\mathrm{m} M$ & $4.20^{\mathrm{a}}$ & $3.87^{\mathrm{a}}$ & $4.07^{\mathrm{a}}$ & $2.57^{\mathrm{b}}$ & 0.50 & $<0.01$ & $<0.01$ & NS \\
\hline Acetate, $\mathrm{m} M$ & $88.6^{\mathrm{a}}$ & $84.8^{\mathrm{ab}}$ & $79.6^{\mathrm{bc}}$ & $74.0^{\mathrm{c}}$ & 3.46 & $<0.01$ & $<0.01$ & NS \\
\hline Propionate, $\mathrm{m} M$ & 29.2 & 29.7 & 30.3 & 31.5 & 2.09 & 0.73 & 0.27 & NS \\
\hline Butyrate, $\mathrm{m} M$ & 16.3 & 15.3 & 15.1 & 14.7 & 1.05 & 0.48 & 0.14 & NS \\
\hline Isobutyrate, $\mathrm{m} M$ & $1.92^{\mathrm{a}}$ & $1.82^{\mathrm{ab}}$ & $1.71^{\mathrm{b}}$ & $1.73^{\mathrm{b}}$ & 0.08 & 0.05 & 0.01 & NS \\
\hline Valerate, $\mathrm{m} M$ & $2.82^{\mathrm{b}}$ & $2.64^{\mathrm{b}}$ & $2.58^{b}$ & $3.36^{\mathrm{a}}$ & 0.24 & 0.01 & 0.06 & 0.01 \\
\hline Isovalerate, $\mathrm{m} M$ & 2.79 & 2.61 & 2.65 & 2.70 & 0.17 & 0.75 & 0.67 & NS \\
\hline Total VFA, $\mathrm{m} M$ & 142 & 137 & 132 & 128 & 6.04 & 0.13 & 0.02 & NS \\
\hline Acetate:propionate & $3.22^{\mathrm{a}}$ & $2.95^{\mathrm{b}}$ & $2.84^{\mathrm{b}}$ & $2.53^{\mathrm{c}}$ & 0.14 & $<0.01$ & $<0.01$ & NS \\
\hline
\end{tabular}

${ }^{\mathrm{a}-\mathrm{c}}$ Means in the same row with different superscripts differ $(P \leq 0.05)$.

${ }^{1} \mathrm{SED}=$ Standard error of the least squares means difference.

${ }^{2} \mathrm{~L}=$ Linear effect; $\mathrm{Q}=$ quadratic effect; $\mathrm{NS}$ = not significant.

energy, metabolizable protein, minerals, and vitamins is similar (Ruppert et al., 2003).

Milk fat content and yield decreased linearly $(P<$ 0.01) when CS replaced AS in the diet (Table 3). For both variables, diet A was highest, diets $B$ and $C$ intermediate, and diet D lowest. Several workers (Onetti et al., 2002; Krause and Combs, 2003; Ruppert et al., 2003) observed increases in milk fat content and yield when AS replaced CS in the diet. Milk fat depression has been associated with increased ruminal concentration of trans-18:1 fatty acids, mainly trans-10 18:1 and trans-10,cis-12 conjugated linoleic acid (Griinari et al., 1998; Baumgard et al., 2000; Onetti et al. 2001). Kalscheur et al. (1997) showed that flow of trans-18:1 fatty acids was increased by feeding a high concentratelow forage diet without buffer compared with the same diet with added buffer. In addition, Onetti et al. (2004) demonstrated that replacing $50 \%$ of CS with AS resulted in 1$)$ a trend $(P<0.14)$ for decreased omasal flow of trans-18:1 (which suggested more complete biohydrogenation), 2) increased chewing activity, 3) higher ruminal $\mathrm{pH}$, and 4) increased milk fat percentage and yield.

In the present trial, mean ruminal $\mathrm{pH}$ over the 24$\mathrm{h}$ feeding cycle did not differ among diets (Table 5); however, a time $\times$ diet interaction $(P<0.01)$ was observed. Therefore, ruminal $\mathrm{pH}$ at $4 \mathrm{~h}$ postfeeding was significantly lower for cows fed diets $\mathrm{C}$ and $\mathrm{D}$ than those fed $\operatorname{diet} \mathrm{A}$ (Figure 1). Moreover, time per day at which ruminal $\mathrm{pH}$ was $<6.0$ was longer for diets with greater proportions of CS (Figure 1). Lower ruminal pH likely was caused by more rapid ruminal fermentation of the greater dietary starch. Krause and Combs (2003) found a significant increase of $1.8 \mathrm{~h} / \mathrm{d}$ during which ruminal $\mathrm{pH}$ was $<5.8$ when CS partially replaced AS. Additionally, CS has a lower buffering capacity than AS (Van Soest et al., 1991). Furthermore, our diets were relatively low in NDF (Table 2), and inadequate intake of effective fiber, especially with greater proportions of CS, may have led to shorter rumination times, reduced salivation, and lower ruminal buffering from saliva. Therefore, lower $\mathrm{pH}$ may have led to incomplete ruminal biohydrogenation of dietary unsaturated fatty acids, resulting in the observed linear decrease in milk fat (Bauman and Griinari, 2001). Linear decreases ( $P$ $<0.01$; Table 5) in ruminal acetate concentration and the acetate:propionate ratio were also found with increasing dietary CS, suggesting a depression of cellulolytic bacteria. A decreased ruminal acetate:propionate ratio has frequently been associated with incomplete ruminal biohydrogenation of dietary linoleic acid (Bauman and Griinari, 2001) and milk fat depression (Gaynor et al., 1995; Griinari et al., 1998; Onetti et al., 2002).

Milk protein content increased linearly $(P<0.01)$ when CS was added to the diets (Table 3). The milk protein concentration of cows fed diet D was $3.2 \%$ higher $(P=0.05)$ than that of cows fed $\operatorname{diet} \mathrm{A}$, whereas cows offered diets B and C were intermediate. Similarly, Moreira et al. (V. R. Moreira, C. Cragnolino, and L. D. Satter, unpublished manuscript) observed a linear 


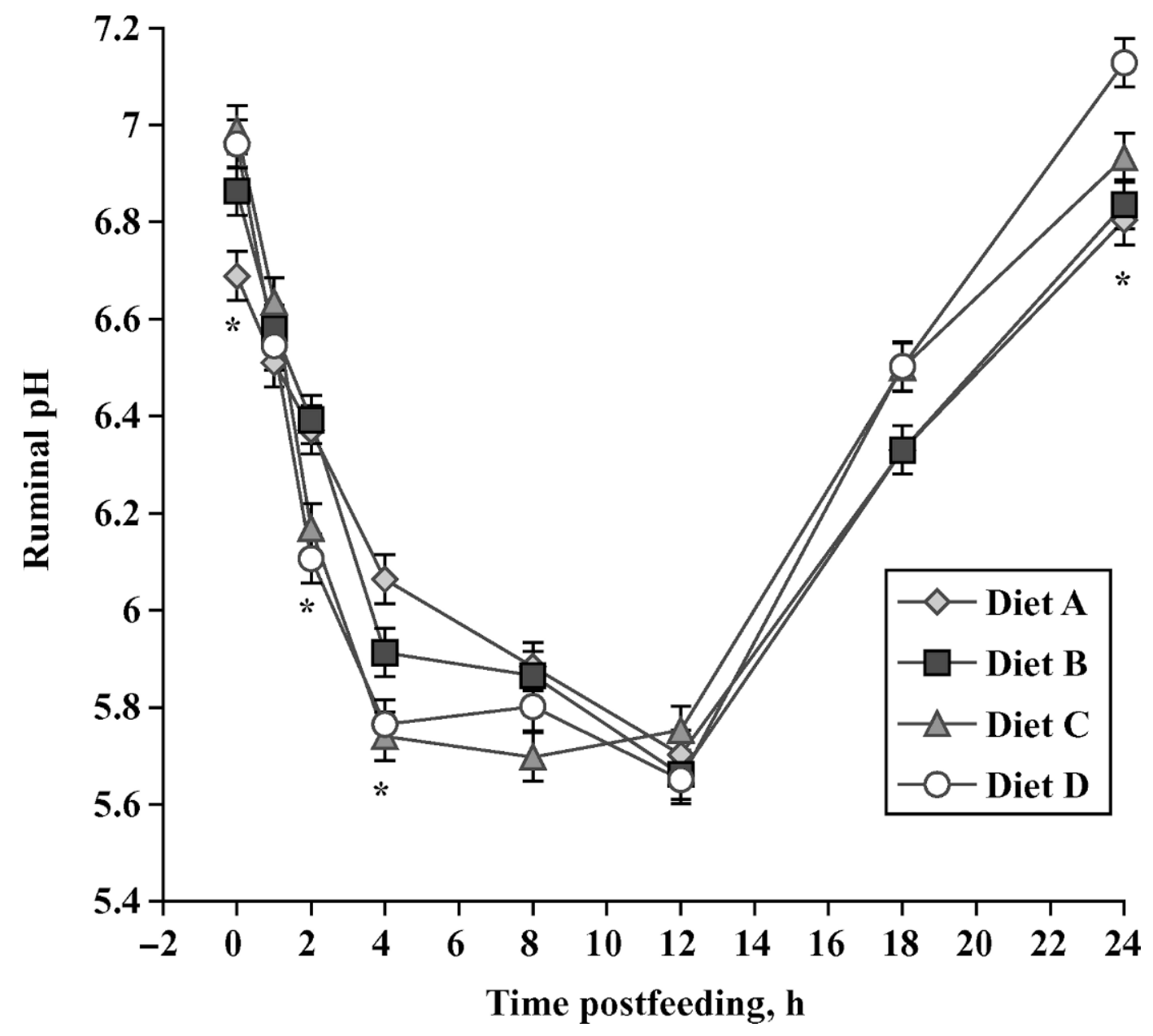

Figure 1. Effects of varying dietary ratios of alfalfa silage (AS) to corn silage (CS) on ruminal pH (means \pm SED) after feeding: diet A (51:0 AS:CS), diet B (37:13 AS:CS), diet C (24:27 AS:CS), and diet D (10:40 AS:CS). A significant time $\times$ diet interaction $(P<0.01)$ was observed and differences among treatments at each sampling time are indicated in the figure $(*)$ : at $0 \mathrm{~h}$ (diet A was lowest, diet B intermediate, and diets $\mathrm{C}$ and $\mathrm{D}$ highest); at $2 \mathrm{~h}$ (diets $\mathrm{A}$ and $\mathrm{B}$ were highest, diet $\mathrm{C}$ intermediate, and diet D lowest); at $4 \mathrm{~h}$ (diet $\mathrm{A}$ was highest, diet $\mathrm{B}$ intermediate, and diets $\mathrm{C}$ and $\mathrm{D}$ lowest); at $24 \mathrm{~h}$ (diets $\mathrm{A}$ and $\mathrm{B}$ were lowest, diet $\mathrm{C}$ intermediate, and diet D highest).

increase in the content of milk protein $(P=0.02)$ when CS replaced AS. Broderick (1985) and Krause and Combs (2003) reported higher percentages of milk protein for cows fed CS-based diets or a diet in which AS was partially replaced by CS. Conversely, Santos (2003) observed a higher milk protein content $(P=0.01)$ for cows fed diets with 70\% AS:30\% CS than those fed diets with 30\% AS:70\% CS. Several authors (Dhiman and Satter, 1997; Onetti et al., 2002; Ruppert et al., 2003) did not report any change in milk protein concentration when CS was included in the diet. The linear increase in milk protein occurred in the present study despite lower microbial NAN flow and similar RUP flow from the rumen measured using omasal sampling (Brito et al., 2006). Therefore, increased milk protein content probably resulted from the linear decrease in milk volume.
Yield of milk protein did not differ among diets (Table $3)$. However, a quadratic effect $(P=0.02)$ was observed, with the quadratic maximum at $31 \%$ dietary AS (Table 4). This indicated that milk protein yield was maximized at a dietary AS:CS ratio of $31: 19$, possibly because of the higher availability of fermentable energy for ruminal microbes. This further supports the complementary characteristics of these forages. A number of authors (Dhiman and Satter, 1997; Onetti et al., 2002; Krause and Combs, 2003) did not observe significant differences in milk protein yield when different dietary ratios of AS:CS were fed in their trials. Broderick (1985) found differences in milk protein yield only when cows were fed a $60 \%$ CS diet vs. diets containing $63 \%$ AS, $60 \%$ alfalfa hay, or $76 \%$ CS.

Milk lactose and SNF content and yield did not differ among diets (Table 3). However, trends for linear $(P=$ 
$0.07)$ and quadratic effects $(P=0.10)$ were observed for milk lactose yield with increasing the proportion of CS. Furthermore, a quadratic effect $(P=0.05)$ was observed for SNF yield with maximum at 35\% dietary AS (Table 4).

A significant effect of the dietary ratio of AS:CS $(P=$ 0.04) was observed for milk NPN concentration (Table 3). Cows offered diets B or C had lower of NPN in milk than those offered diet $\mathrm{D}$, whereas cows fed $\operatorname{diet} \mathrm{A}$ were intermediate. A quadratic effect $(P<0.01)$, with minimum at $31 \%$ AS, also was found (Table 4 ), suggesting that a 31:19 ratio of AS:CS would minimize NPN secretion in milk. The higher milk NPN concentration in cows fed diet D compared with diets B or C was surprising because replacing AS with CS plus SSBM reduced the dietary NPN intake. In addition, ruminal ammonia was lowest on diet D (Table 5), which also was inconsistent with the elevated milk NPN on that diet. However, 41 (diet A) and $43 \%$ (diets B through D) of the total milk NPN came from urea. Brito (2004) observed that 58 and $48 \%(P<0.01)$ of the total milk NPN came from urea on, respectively, AS diets (higher in NPN) vs. RCS diets (lower in NPN). Because Brito (2004) found no difference in total milk NPN content among diets, it can be concluded that nonurea $\mathrm{N}$ compounds compensated for the lower MUN in the RCS diets.

Concentrations of MUN were similar among treatments (Table 3) despite the higher NPN content in AS vs. CS and the small reduction in CP from $\operatorname{diet} \mathrm{A}$ to $\operatorname{diet}$ D. Wattiaux and Karg (2004a) also found that MUN did not differ on high-AS vs. high-CS diets. In general, higher MUN is expected in diets with greater dietary $\mathrm{CP}$ content and intake. Olmos Colmenero and Broderick (2006) observed a linear increase in MUN, from 7.7 to $15.6 \mathrm{mg} / \mathrm{dL}$, when dietary CP was increased from 13.5 to $19.4 \%$. Broderick and Clayton (1997) and Nousiainen et al. (2004) concluded that dietary CP content was the best single predictor of MUN, accounting for, respectively, 0.84 and 0.78 of total variance. Santos (2003) reported that MUN increased from 9.1 to $13.8 \mathrm{mg} / \mathrm{dL}$ when the dietary CP increased from 14.9 to $18.1 \% \mathrm{CP}$ on high-AS diets and from 10.0 to $16.2 \mathrm{mg} / \mathrm{dL}$ when the dietary CP levels increased from 15.4 to $18.5 \% \mathrm{CP}$ on high-CS diets. Wattiaux and Karg (2004a) observed that reducing CP from 17.5 to $16.4 \%$ lowered MUN from 12.7 to $11.7 \mathrm{mg} / \mathrm{dL}$. Generally, urea concentrations in blood and milk are similar (Broderick and Clayton, 1997). However, BUN was highest on diets $C$ and D, intermediate on $\operatorname{diet} \mathrm{A}$, and lowest on $\operatorname{diet} \mathrm{B}$ (Table 3) despite the lack of a significant effect of diet on MUN. It is possible that these effects were related to asynchronous release of energy and RDP in the rumen on diets with greater proportions of CS. When CS was increased and AS reduced, HMSC was dropped from 43.3 (diet
A) to $30.5 \%$ of DM (diet D) and the difference of 13 percentage units was made up with SSBM (Table 2). The slower release of RDP from diets $\mathrm{C}$ and $\mathrm{D}$ might have impaired the synchrony of energy and RDP availability in the rumen, thereby reducing the efficiency of utilization of both energy and N. Broderick (1985) observed higher BUN on CS than on AS diets. On the other hand, Dhiman and Satter (1997) reported higher BUN on diets containing AS as the sole forage source vs. diets in which CS partially replaced AS. Higher BUN levels on diets $\mathrm{C}$ and $\mathrm{D}$ were somewhat surprising because of the reduction of NPN and CP intakes that occurred when replacing AS plus HMSC with CS plus SSBM. However, BUN was determined in blood samples taken at a single time ( $4 \mathrm{~h})$ after feeding, whereas MUN values were derived from both daily milk samples on test days. Although blood and milk urea equilibrate rapidly, BUN rises and falls throughout the day, reflecting the dynamic nature of $\mathrm{N}$ metabolism (Gustafsson and Palmquist, 1993).

Although there were substantial differences in DMI, the BW change did not differ, averaging $0.98 \mathrm{~kg} / \mathrm{d}$ among diets (Table 3). Broderick (1985), in one of 2 trials, and Santos (2003) also found no difference in BW change comparing AS vs. CS diets. However, in a second trial, Broderick (1985) observed greater daily BW gain for cows fed a diet with $60 \%$ CS vs. cows fed diets with $60 \%$ AS or $79 \%$ CS. In the present experiment, feed efficiency increased linearly $(P<0.01)$ when CS plus SSBM replaced AS plus HMSC (Table 3), with cows fed diets $\mathrm{C}$ or $\mathrm{D}$ being higher $(P<0.01)$ than those fed diets A or B. As discussed earlier, lower DMI on diets with greater proportions of CS was possibly caused by the higher starch intake and lower ruminal $\mathrm{pH}$. Feed efficiency was computed from only the last $2 \mathrm{wk}$ of each 4-wk period in our 16-wk trial. Moreira et al. (V. R. Moreira, C. Cragnolino, and L. D. Satter, unpublished manuscript) stated that feed efficiency data should be interpreted cautiously in short-term reversal trials because cows may mobilize body reserves to maintain production. However, large apparent $\mathrm{BW}$ gains and the lack of significant differences in BW change in the present study suggested no mobilization of fat from adipose tissue. When feed efficiency was expressed as 3.5\% FCM:DMI, no significant differences were observed among diets (Table 3).

\section{Apparent Total Tract Digestibility and Ruminal Metabolism}

Apparent total tract digestibilities of DM, OM, and hemicellulose did not differ among diets, averaging 66, 67 , and $23 \%$, although a trend $(P=0.08)$ for a linear increase in OM digestibility with increasing CS and 
SSBM was detected (Table 5). Apparent digestibility of DM (V. R. Moreira, C. Cragnolino, and L. D. Satter, unpublished manuscript) and of DM and OM did not alter when different dietary ratios of AS:CS were fed (Ruppert et al., 2003; Krause and Combs, 2003). However, DM digestibility was significantly higher for diets containing forage from CS vs. AS in other trials (Broderick, 1985; Hristov and Broderick, 1996), whereas Santos (2003) found the opposite effect. Apparent digestibilities of NDF and ADF decreased linearly and quadratically when CS replaced AS, and both variables were lowest in cows fed diet D (Table 5). The quadratic maxima for apparent digestibility of NDF and ADF were, respectively, 50 and $44 \%$ dietary AS (Table 4). Ruppert et al. (2003) also reported greater NDF and ADF digestibility in high-AS compared with high-CS diets, and other workers observed this effect for ADF only (Broderick, 1985; Krause and Combs, 2003; V. R. Moreira, C. Cragnolino, and L. D. Satter, unpublished manuscript). Neutral detergent fiber and ADF digestibilities appeared to be low and can be explained partly by the high DMI, which averaged $25.6 \mathrm{~kg} / \mathrm{d}$ across diets in the present trial. High DMI can increase the ruminal passage rate, leading to reduced fiber digestibility. Alternatively, Huhtanen et al. (1994) and Reynal and Broderick (2005) suggested that the lower fecal recovery of dietary NDF estimated in situ using bags with pore sizes of $41 \mu \mathrm{m}$ compared with bags of $6-\mu \mathrm{m}$ pore size was due to a greater relative loss of particles from fecal than feed samples. Therefore, greater loss of indigestible $\mathrm{ADF}$ from fecal rather than dietary samples placed in Ankom bags with a $21-\mu \mathrm{m}$ pore size in the current study may have resulted in overestimation of fecal excretion and underestimation of total tract digestibility. Additionally, the CS used in this trial was relatively dry (45\% DM), indicating advanced maturity of the corn plant at harvest, which may also have limited fiber digestibility.

The moisture content of the whole-plant corn is inversely related to stage of maturity at harvest (Wiersma et al., 1993). Bal et al. (1997) fed lactating dairy cows silages containing $30,32,35$, and $42 \%$ DM made from whole-plant corn harvested at, respectively, the early dent, quarter milkline, two-thirds milkline, and blacklayer stages. Apparent total tract digestion of DM, $\mathrm{OM}, \mathrm{CP}, \mathrm{ADF}$, and starch all were lowest for cows fed CS harvested at the blacklayer stage, which had moisture content similar to the CS fed in the current trial. The starch content of the corn plant increases as it matures (Bal et al., 1997). Thus, lowered fiber digestibility because of high starch intake from feeding relatively mature CS may also be attributed to depressed ruminal $\mathrm{pH}$. Fiber digestibility decreases when ruminal $\mathrm{pH}$ drops below 6.0 for extended periods of time (Allen,
1997), probably because cellulolytic activity is reduced below this threshold (Grant and Mertens, 1992). In the current study, mean ruminal $\mathrm{pH}$ over the 24-h feeding cycle did not differ among diets (Table 5). However, ruminal $\mathrm{pH}$ was reduced $2 \mathrm{~h}$ postfeeding on diet $\mathrm{D}$ compared with diets $\mathrm{A}$ and $\mathrm{B}$ and also $4 \mathrm{~h}$ postfeeding on diets $\mathrm{C}$ or $\mathrm{D}$ compared with $\operatorname{diet} \mathrm{A}$, and was $<6.0$ for longer time periods when CS was fed (Figure 1). Regressing the magnitude of the diurnal fluctuation of ruminal $\mathrm{pH}(\mathrm{pH}$ at peak $-\mathrm{pH}$ at nadir) on total tract fiber digestibility yielded regression coefficients of 0.90 for NDF and of 0.86 for ADF (Figure 2), which strongly suggested that depressed $\mathrm{pH}$ was responsible for reduced cellulolysis. Moreira et al. (V. R. Moreira, C. Cragnolino, and L. D. Satter, unpublished manuscript) used the same approach to demonstrate that the reduced ADF digestibility in their trial was likely caused by depressed cellulolytic activity because of the diurnal $\mathrm{pH}$ fluctuation. These authors speculated that greater oscillation of ruminal $\mathrm{pH}$ might lead to longer periods during the day when growth of the cellulolytic bacteria was depressed, resulting in reduced fiber digestibility.

Although linear decreases in total tract apparent digestibility of NDF and ADF were observed when CS replaced AS (Table 5), no significant differences were found when omasal sampling was used to estimate ruminal digestibility of NDF (percentage of intake and amount) and $\mathrm{ADF}$ (percentage of intake) in cannulated cows fed these same diets (Brito et al., 2006). This apparent inconsistency may have been related to the use of different digestion markers discussed earlier. In addition, a larger data set was used in the statistical analysis of apparent total tract digestibility ( 27 or 28 observations/diet), whereas fewer omasal flow measurements (8 observations/diet) were made in determining ruminal digestibility. Total tract digestibility of $\mathrm{NDF}$ and $\mathrm{ADF}$ also had lower variation $(\mathrm{SED}=1.10$ and $0.91 \%$, respectively) than did ruminal digestibility of $\mathrm{NDF}$ and $\mathrm{ADF}$ (SED = 3.44 and $3.81 \%$, respectively; Brito et al., 2006). When total tract NDF and ADF digestibilities in the 8 ruminally cannulated cows were analyzed separately, treatment differences were again observed ( $P=0.04$ and $P=0.01$, respectively; data not shown), probably because of lower variation (SED = 2.35 and $2.02 \%$, respectively). Variation in the omasal sampling technique may have prevented detection of treatment differences for ruminal fiber digestion.

Overall, the lower production of cows fed diet D probably reflected excessive starch intake, lower ruminal $\mathrm{pH}$ and fiber digestion, and resulting depression in DMI. However, all diets contained high NFC levels and the feeding of a mature CS with elevated starch content may have made these cows more susceptible to digestive 


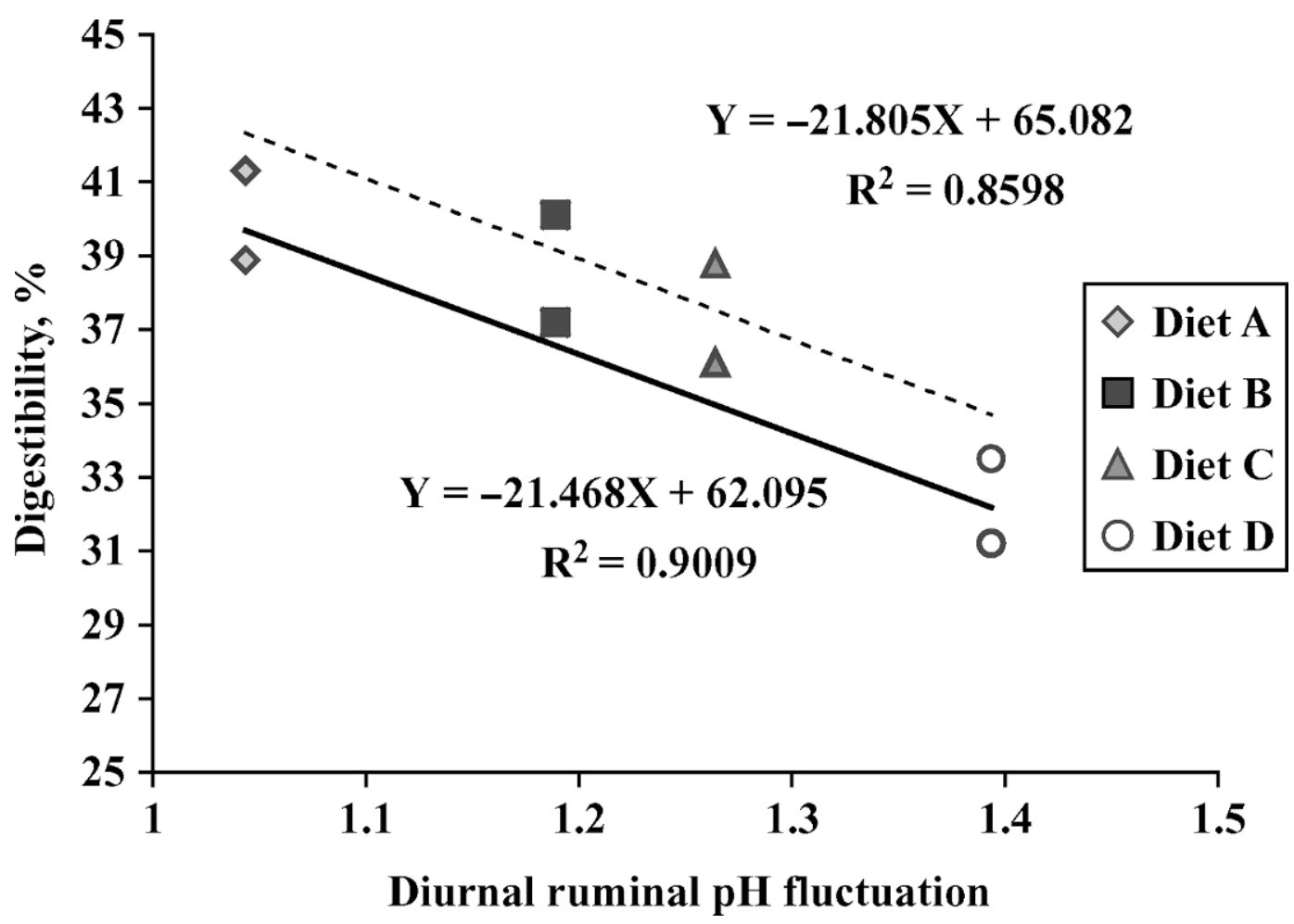

Figure 2. Effects of daily fluctuation of ruminal $\mathrm{pH}$ on apparent total tract digestibility of fiber in cows fed varying ratios of alfalfa silage to corn silage. Neutral detergent fiber digestibility is represented by the solid line and ADF digestibility by the dashed line. Each symbol represents the least squares mean on each diet. Daily fluctuation of ruminal $\mathrm{pH}$ was measured by subtracting the ruminal $\mathrm{pH}$ nadir from the peak ruminal $\mathrm{pH}$.

upset. Thus, optimal AS:CS ratios may be somewhat different on diets containing more normal levels of NFC.

As expected, ruminal ammonia concentrations were 41,38 , and $29 \%$ higher $(P<0.01)$ on diets A, B and C, respectively, than on diet $\mathrm{D}$ (Table 5). This linear effect on ammonia was likely associated with the replacement of CP from AS (a large proportion of which is present as NPN; Table 1) plus HMSC with that from CS plus SSBM, which is more resistant to ruminal degradation (NRC, 2001). In addition, there was a small reduction in $\mathrm{CP}$ from diet $\mathrm{A}$ to $\operatorname{diet} \mathrm{D}$ (Table 2) and the RDP supply, measured using omasal sampling, also decreased linearly (Brito et al., 2006), both of which would contribute to reduced ruminal ammonia. Literature reports on the response of ruminal ammonia to altered dietary AS:CS ratios have been inconsistent. Broderick (1985), in one trial, Hristov and Broderick (1996), and Dhiman and Satter (1997) all observed lower ammonia concentrations with CS than with AS diets, whereas Broderick (1985), in a second trial, Onetti et al. (2002), and Onetti et al. (2004) found no differences. Furthermore, Ruppert et al. (2003) reported greater levels of ruminal ammonia on diets high in CS vs. diets high in $\mathrm{AS}$.
A linear decrease $(P<0.01)$ in the ruminal concentration of total free AA was observed with increasing dietary CS, with cows fed diet D being lowest $(P<0.01$; Table 5). This reduction likely occurred because NPN intake from AS, most of which is present as free AA (Luchini et al., 1997), decreased as CS plus SSBM replaced AS plus HMSC. In a previous trial (Brito, 2004), AS diets with greater NPN and RDP were, on average, $31 \%$ higher $(P<0.01)$ in ruminal total free AA than RCS diets with lower NPN and RDP. Dhiman and Satter (1997) also observed a significant reduction in total free AA in the rumen when incremental amounts of CS were added to their diets.

The total VFA concentration was not affected by diet. However, ruminal acetate decreased linearly $(P<0.01)$ when CS replaced AS in the diet (Table 5), which, as discussed, may be related to the length of time when $\mathrm{pH}$ was $<6.0$; ruminal acetate was highest $(P<0.01)$ on $\operatorname{diet} \mathrm{A}$, intermediate on diets $\mathrm{B}$ and $\mathrm{C}$, and lowest on diet D. Several authors (Hristov and Broderick, 1996; Onetti et al., 2002; Onetti et al., 2004) also reported reduced ruminal acetate concentrations when comparing CS diets with AS diets or when AS was partially replaced by CS. Ruminal concentrations of propionate 
Table 6. Effects of varying dietary ratios of alfalfa silage (AS) to corn silage (CS) on urinary N excretion, $\mathrm{N}$ efficiency, and fecal $\mathrm{N}$ excretion in lactating dairy cows

\begin{tabular}{|c|c|c|c|c|c|c|c|c|}
\hline \multirow[b]{2}{*}{ Item } & \multicolumn{4}{|c|}{ Diet (AS:CS) } & \multirow[b]{2}{*}{$\mathrm{SED}^{1}$} & \multicolumn{3}{|c|}{ Significance $^{2}(P$-value $)$} \\
\hline & $\mathrm{A}(51: 0)$ & B $(37: 13)$ & $\mathrm{C}(24: 27)$ & $\mathrm{D}(10: 40)$ & & Diet & $\mathrm{L}$ & $\mathrm{Q}$ \\
\hline Total volume, L/d & $29.1^{\mathrm{a}}$ & $24.4^{\mathrm{b}}$ & $21.5^{\mathrm{c}}$ & $17.6^{\mathrm{d}}$ & 1.48 & $<0.01$ & $<0.01$ & NS \\
\hline $\mathrm{N}$ intake, $\mathrm{g} / \mathrm{d}$ & $744^{\mathrm{a}}$ & $719^{\mathrm{b}}$ & $675^{\mathrm{c}}$ & $617^{\mathrm{d}}$ & 12.3 & $<0.01$ & $<0.01$ & 0.06 \\
\hline \multicolumn{9}{|l|}{ Urinary excretion } \\
\hline Total N, g/d & $217^{\mathrm{a}}$ & $215^{\mathrm{a}}$ & $201^{\mathrm{b}}$ & $188^{\mathrm{b}}$ & 7.05 & $<0.01$ & $<0.01$ & NS \\
\hline Total $\mathrm{N}, \%$ of $\mathrm{N}$ intake & 29.4 & 30.0 & 30.2 & 31.2 & 1.11 & 0.42 & 0.10 & NS \\
\hline Urea $\mathrm{N}, \mathrm{g} / \mathrm{d}$ & $183^{\mathrm{a}}$ & $165^{\mathrm{b}}$ & $158^{\mathrm{b}}$ & $157^{\mathrm{b}}$ & 7.29 & $<0.01$ & $<0.01$ & 0.10 \\
\hline Urea $N, \%$ of total $N$ & $84.6^{\mathrm{a}}$ & $78.4^{\mathrm{b}}$ & $78.9^{b}$ & $84.2^{\mathrm{a}}$ & 2.51 & 0.01 & 0.84 & $<0.01$ \\
\hline Urea $\mathrm{N}, \%$ of $\mathrm{N}$ intake & 25.0 & 23.3 & 24.0 & 25.7 & 1.21 & 0.20 & 0.50 & 0.04 \\
\hline Allantoin, $\mathrm{mmol} / \mathrm{d}$ & 367 & 386 & 392 & 383 & 14.1 & 0.29 & 0.20 & NS \\
\hline \multicolumn{9}{|l|}{ Fecal excretion } \\
\hline $\mathrm{DM}, \mathrm{kg} / \mathrm{d}$ & $9.30^{\mathrm{a}}$ & $9.18^{\mathrm{a}}$ & $8.41^{b}$ & $8.18^{\mathrm{b}}$ & 0.27 & $<0.01$ & $<0.01$ & NS \\
\hline $\mathrm{OM}, \mathrm{kg} / \mathrm{d}$ & $8.37^{\mathrm{a}}$ & $8.31^{\mathrm{a}}$ & $7.67^{\mathrm{b}}$ & $7.44^{\mathrm{b}}$ & 0.26 & $<0.01$ & $<0.01$ & NS \\
\hline $\mathrm{NDF}, \mathrm{kg} / \mathrm{d}$ & 3.80 & 3.91 & 3.84 & 3.94 & 0.10 & 0.45 & 0.23 & NS \\
\hline $\mathrm{ADF}, \mathrm{kg} / \mathrm{d}$ & $2.53^{\mathrm{a}}$ & $2.37^{\mathrm{b}}$ & $2.18^{\mathrm{c}}$ & $2.08^{\mathrm{d}}$ & 0.05 & $<0.01$ & $<0.01$ & NS \\
\hline $\mathrm{N}, \mathrm{g} / \mathrm{d}$ & $275^{\mathrm{a}}$ & $263^{\mathrm{a}}$ & $230^{\mathrm{b}}$ & $211^{\mathrm{b}}$ & 10.2 & $<0.01$ & $<0.01$ & NS \\
\hline $\mathrm{N}, \%$ of $\mathrm{N}$ intake & $37.0^{\mathrm{a}}$ & $36.4^{\mathrm{a}}$ & $33.8^{\mathrm{b}}$ & $34.0^{\mathrm{b}}$ & 1.21 & 0.01 & $<0.01$ & NS \\
\hline \multicolumn{9}{|l|}{ Total N excretion } \\
\hline $\mathrm{g} / \mathrm{d}$ & $491^{\mathrm{a}}$ & $479^{\mathrm{a}}$ & $431^{\mathrm{b}}$ & $400^{c}$ & 12.3 & $<0.01$ & $<0.01$ & NS \\
\hline$\%$ of $\mathrm{N}$ intake & 66.5 & 66.6 & 64.1 & 65.3 & 1.40 & 0.27 & 0.21 & NS \\
\hline \multicolumn{9}{|l|}{$\mathrm{N}$ efficiency } \\
\hline Milk $\mathrm{N}, \%$ of $\mathrm{N}$ intake & $26.5^{\mathrm{d}}$ & $28.5^{\mathrm{c}}$ & $30.0^{\mathrm{b}}$ & $31.7^{\mathrm{a}}$ & 0.54 & $<0.01$ & $<0.01$ & NS \\
\hline $\mathrm{kg}$ of milk:kg of $\mathrm{N}$ excreted & $85.7^{\mathrm{b}}$ & $89.7^{\mathrm{b}}$ & $98.9^{\mathrm{a}}$ & $101^{\mathrm{a}}$ & 2.89 & $<0.01$ & $<0.01$ & NS \\
\hline
\end{tabular}

${ }^{\mathrm{a}-\mathrm{d}}$ Means in the same row with different superscripts differ $(P \leq 0.05)$.

${ }^{1} \mathrm{SED}=$ Standard error of the least squares means difference

${ }^{2} \mathrm{~L}=$ Linear effect; $\mathrm{Q}=$ quadratic effect; $\mathrm{NS}$ = not significant.

and butyrate averaged 30 and $15 \mathrm{mM}$ and did not differ among diets in the present trial (Table 5). Dhiman and Satter (1997) and Krause and Combs (2003) also did not observe significant differences in the concentrations of these 2 VFA. Because ruminal acetate decreased and ruminal propionate was similar across diets, the acetate:propionate ratio declined linearly $(P<0.01)$ by replacing AS plus HMSC with CS plus SSBM and was lowest $(P<0.01)$ on diet D (Table 5). Ruminal isobutyrate also decreased linearly $(P=0.01)$ from $\operatorname{diet} \mathrm{A}$ to $\operatorname{diet} \mathrm{D}$ and differed across diets $(P=0.05)$, whereas no treatment effects were observed for ruminal isovalerate (Table 5). Valerate tended to increase linearly $(P=0.06)$ and was higher $(P=0.01)$ on diet $\mathrm{D}$ than on the other 3 diets; a quadratic effect $(P=0.01)$, with minimum at $35 \%$ dietary AS (Table 4), also was detected for this variable. The total VFA concentration decreased linearly $(P=0.02)$ as CS replaced AS.

\section{Nutrient Utilization and Excretion}

Urine volume decreased linearly $(P<0.01)$ from diet A to diet $\mathrm{D}$ (Table 6), probably reflecting the relatively high potassium content of AS (NRC, 2001). Hristov and Broderick (1996) and Santos (2003) also reported greater urine volumes on diets with greater dietary AS vs. CS. As expected, total urinary $\mathrm{N}$ excretion decreased linearly $(P<0.01)$ with replacement of AS plus HMSC with CS plus SSBM in the diet (Table 6). No difference was observed between diets $A$ and $B$ and between diets $\mathrm{C}$ and $\mathrm{D}$, but cows fed the former pair of diets excreted $22 \mathrm{~g} / \mathrm{d}$ more urinary $\mathrm{N}(P<0.01)$ than cows fed the latter pair of diets. However, total $\mathrm{N}$ in urine did not differ when expressed as a percentage of $\mathrm{N}$ intake and averaged $30 \%$ (Table 6). The linear decrease in urinary $\mathrm{N}$ excretion probably was caused by the linear reduction $(P<0.01)$ in N intake (Tables 3 and 6). Previously, Brito (2004) found that cows fed AS-based diets consumed $83 \mathrm{~g} / \mathrm{d}$ more $\mathrm{N}(P<0.01)$ and excreted $25 \%$ more $\mathrm{N}$ in urine $(P<0.01)$ than those fed RCS-based diets. Conversely, Ruppert et al. (2003) reported that cows fed high-AS diets and consuming $64 \mathrm{~g} / \mathrm{d}$ more $\mathrm{N}(P<$ $0.01)$ excreted no more urinary $\mathrm{N}$ than cows fed high-CS diets. Thus, urinary $\mathrm{N}$ excretion may not only depend on $\mathrm{N}$ intake, and these discrepancies likely are related to utilization and retention of N. Ruppert et al. (2003) reported greater productive $\mathrm{N}$ and retained $\mathrm{N}$ on highAS vs. high-CS diets. Their results showed high $\mathrm{N}$ retentions, with values varying from 275 to $712 \mathrm{~g} / \mathrm{d}$ of retained protein on diets containing high $\mathrm{CS}+2 \%$ tallow or high AS $+2 \%$ tallow, respectively. Assuming body tissues contain about $20 \%$ protein, these values represent BW gains of up to $3.2 \mathrm{~kg} / \mathrm{d}$, suggesting overestimation of $\mathrm{N}$ retention according to these authors. In addition, $\mathrm{N}$ intake was $9 \%$ greater in the high-AS diets. However, productive $\mathrm{N}$ (sum of milk $\mathrm{N}$ plus retained 
N) did not differ among diets when expressed as a percentage of $\mathrm{N}$ intake.

Excretion of urinary urea $\mathrm{N}$ also decreased linearly $(P<0.01)$, from $183 \mathrm{~g} / \mathrm{d}(\operatorname{diet} \mathrm{A})$ to $157 \mathrm{~g} / \mathrm{d}(\operatorname{diet} \mathrm{D})$, with reduced dietary AS and $\mathrm{CP}$ (Table 6), and was greater on $\operatorname{diet} \mathrm{A}(P<0.01)$ than on $\operatorname{diets} \mathrm{B}, \mathrm{C}$, and $\mathrm{D}$. Wattiaux and Karg (2004b) also reported a mean $40 \mathrm{~g} / \mathrm{d}$ reduction in urinary excretion of urea $\mathrm{N}$ when dietary protein was reduced from 17.6 to $16.4 \%$ CP. When expressed as a percentage of total $\mathrm{N}, 84.6$ and $84.2 \%$ of total urinary $\mathrm{N}$ was excreted as urea on diets $\mathrm{A}$ and $\mathrm{D}$, and 78.4 and $78.9 \%$ on diets $\mathrm{B}$ and $\mathrm{C}$, respectively. These data showed that inclusion of up to $27 \% \mathrm{CS}$ reduced $(P=0.01)$ the contribution of urea $\mathrm{N}$ to total urinary $\mathrm{N}$ (Table 6). A quadratic effect for this variable also was observed, with the quadratic minimum at $30 \%$ AS (Table 4). Although urea accounts for the majority of urinary $\mathrm{N}$, proportions of urea $\mathrm{N}$ in total urinary $\mathrm{N}$ can be altered by diet. Olmos Colmenero and Broderick (2006) observed that urea accounted for between 55\% (at 13.5\% dietary $\mathrm{CP}$ ) and $82 \%$ (at $19.4 \% \mathrm{CP}$ ) of total urinary $\mathrm{N}$. High proportions or amounts of urinary $\mathrm{N}$ being excreted as urea are undesirable because urease in manure rapidly degrades urea to ammonia, which may volatilize and contribute to environmental pollution. Urinary allantoin excretion did not differ and averaged $382 \mathrm{mmol} / \mathrm{d}$ across diets (Table 6). This suggested that there were no dietary effects on ruminal synthesis of microbial protein. Using allantoin to estimate microbial protein synthesis, Krause and Combs (2003) also found no differences comparing diets with forage fed as all AS vs. forage fed as a 50:50 ratio of AS:CS.

Fecal $\mathrm{N}$ excretion decreased linearly $(P<0.01)$ when CS plus SSBM replaced dietary AS plus HMSC (Table $6)$. Cows fed diets A and B excreted more fecal N $(P<$ 0.01 ) than those fed diets $C$ and D. Similar results were observed for fecal $\mathrm{N}$ excretion expressed as a percentage of $\mathrm{N}$ intake (Table 6). Ruppert et al. (2003) and Wattiaux and Karg (2004b) reported increases of 13 and $23 \%$, respectively, in the excretion of fecal $\mathrm{N}$ when feeding high-AS vs. high-CS diets, whereas Santos (2003) found no difference using similar diets. As expected, total N excretion (feces plus urine) decreased linearly $(P<0.01)$ from $\operatorname{diet} \mathrm{A}$ to diet $\mathrm{D}$, an overall reduction of $19 \%$ (Table 6). Wattiaux and Karg (2004b) observed an 11\% reduction in total $\mathrm{N}$ excretion when high-AS diets were replaced with high-CS diets. There were no differences among diets when total manure $\mathrm{N}$ was expressed as a percentage of $\mathrm{N}$ intake, with an average $66 \%$ of $\mathrm{N}$ consumed excreted in urine and feces. Others (Castillo et al., 2001a; Castillo et al., 2001b; Wattiaux and Karg, 2004b) observed similar ratios of manure N:N intake in their trials. Nitrogen efficiency, expressed either as milk N:N intake or as kilograms of milk yield per kilo- gram of total $\mathrm{N}$ excreted, increased linearly $(P<0.01)$ when CS plus SSBM replaced AS plus HMSC in the diet. However, $\mathrm{N}$ efficiency data should be interpreted cautiously because of the decreased $\mathrm{N}$ intake as CS was increased in the ration. Although cows fed diet $\mathrm{D}$ were the most $\mathrm{N}$ efficient, they also had the lowest DMI, milk yield, and milk fat content and yield. Thus, it may not be possible to simultaneously maximize animal production and minimize $\mathrm{N}$ waste. In a previous trial (Brito, 2004), cows fed RCS diets excreted less $\mathrm{N}$ in urine and feces and tended to be more $\mathrm{N}$ efficient than those fed the AS diets, but production also was significantly reduced. In the present study, cows offered diet $\mathrm{C}$ were able to maintain milk production and milk protein content and yield, and had the next to lowest total $\mathrm{N}$ excretion, suggesting that the AS:CS ratio of that diet (24:27) might approximate the equilibrium point at which production is maintained with minimal $\mathrm{N}$ excretion. Brito (2004) also observed that, despite reduced N excretion, animal production was negatively affected by decreasing the RDP supply from $14.5 \%$ of DM on AS diets to $11.8 \%$ of DM on RCS diets. Reynal and Broderick (2005) demonstrated that decreasing RDP levels from 13.2 to $11.7 \%$ of DM reduced $\mathrm{N}$ excretion but maintained yields of milk and milk protein, whereas cows fed a diet with $10.6 \%$ RDP had both decreased urinary $\mathrm{N}$ excretion and milk protein yield. In the present study (Brito et al., 2006), a linear reduction $(P<0.01)$ in RDP from $11.7 \%$ (diet A) to $10.1 \%$ of DM (diet D), measured by omasal sampling, accompanied the linear declines in total $\mathrm{N}$ excretion and milk yield. However, production was maintained, $\mathrm{N}$ and feed efficiency increased, and total urinary $\mathrm{N}$ excretion reduced on $\operatorname{diet} \mathrm{C}$, which contained 10.5\% RDP. Different optima for dietary RDP among different experiments suggested that the cutoff point for RDP will vary with dietary sources of forage, concentrate, and protein supplement.

\section{CONCLUSIONS}

Under the conditions of this study, decreasing dietary AS and HMSC and increasing dietary CS and SSBM reduced DM intake and contributed to greater fluctuation in ruminal $\mathrm{pH}$ and to ruminal $\mathrm{pH}$ remaining $<6.0$ for longer periods during the day. This may have contributed to reduced milk fat content and yield and depressed milk production when the diet contained an AS:CS ratio of 10:40. Urinary urea and total $N$ excretion decreased linearly when dietary AS plus HMSC were replaced with CS plus SSBM, which was related to a linear decrease in $\mathrm{N}$ intake. Considering only environmental $\mathrm{N}$ losses, diets containing minimal AS would be preferred. However, animal productivity (milk yield, milk fat content and yield, and fiber digestibility) also 
decreased linearly with decreasing dietary AS. The equilibrium point, at which $\mathrm{N}$ excretion was reduced without loss of animal production, was obtained on the diet with an AS:CS ratio of 24:27. Based on these findings, inclusion of CS in AS-based diets is strongly recommended because of the positive interactions of these forages on intake, yield, and $\mathrm{N}$ utilization. Moisture content of the CS fed in this trial suggested that the corn plant was overly mature at harvest and would have had a higher than normal starch content. In addition, dietary NFC was higher than recommended by the NRC (2001), which may have resulted in detrimental effects in the rumen and on production on diets containing higher proportions of CS. Optimal AS:CS ratios may be different on diets containing more normal levels of NFC.

\section{ACKNOWLEDGMENTS}

The authors thank Rick Walgenbach and the farm crew for harvesting and storing the feeds and Len Strozinski and the barn crew for animal care and sampling at the US Dairy Forage Research Farm (Prairie du Sac, WI); Jose de Jesus Olmos Colmenero, Santiago Reynal, Wendy Radloff, Fern Kanitz, Mary Becker, Adam Ford, and Antonio Faciola for assistance with sampling and laboratory analyses; and Peter Crump for assisting with the statistical analyses.

\section{REFERENCES}

Allen, M. S. 1997. Relationship between fermentation acid production in the rumen and the requirement for physically effective fiber. J. Dairy Sci. 80:1447-1462.

AOAC. 1980. Official Methods of Analysis. 13th ed. AOAC, Washington, DC.

AOAC. 1990. Official Methods of Analysis. 15th ed. AOAC, Arlington, VA.

Bal, M. A., J. G. Coors, and R. D. Shaver. 1997. Impact of the maturity of corn for use as silage in the diets of dairy cows on intake, digestion, and milk production. J. Dairy Sci. 80:2497-2503.

Bauman, D. E., and J. M. Griinari. 2001. Regulation and nutritional manipulation of milk fat: low-fat milk syndrome. Livestock Prod. Sci. 70:15-29.

Baumgard, L. H., B. A. Corl, D. A. Dwyer, A. Saebo, and D. E. Bauman. 2000. Identification of the conjugated linoleic acid isomer that inhibits milk fat synthesis. Am. J. Physiol. 278:R179-R184.

Brito, A. F. 2004. Effects of dietary forage and protein supplements on production, nitrogen utilization, and microbial protein synthesis in lactating dairy cows. PhD Thesis, University of WisconsinMadison, Madison.

Brito, A. F., G. A. Broderick, and S. M. Reynal. 2006. Effect of varying dietary ratios of alfalfa silage to corn silage on omasal flow and microbial protein synthesis in dairy cows. J. Dairy Sci. 89:3939-3953.

Broderick, G. A. 1985. Alfalfa silage or hay versus corn silage as the sole forage for lactating dairy cows. J. Dairy Sci. 68:3262-3271.

Broderick, G. A. 1987. Determination of protein degradation rates using a rumen in-vitro system containing inhibitors of microbial nitrogen metabolism. Br. J. Nutr. 58:463-476.

Broderick, G. A., and M. K. Clayton. 1997. A statistical evaluation of animal and nutritional factors influencing concentrations of milk urea nitrogen. J. Dairy Sci. 80:2964-2971.
Broderick, G. A., and J. H. Kang. 1980. Automated simultaneous determination of ammonia and total amino acids in ruminal fluid and in vitro media. J. Dairy Sci. 63:64-75.

Brotz, P. G., and D. M. Schaefer. 1987. Simultaneous determination of lactic acid and volatile fatty acids in microbial fermentation extracts by gas-liquid chromatography. J. Microbiol. Methods 6:139-144.

Castillo, A. R., E. Kebreab, D. E. Beever, J. H. Barbi, J. D. Sutton, H. C. Kirby, and J. France. 2001a. The effect of protein supplementation on nitrogen utilization in lactating dairy cows fed grass silage diets. J. Anim. Sci. 79:247-253.

Castillo, A. R., E. Kebreab, D. E. Beever, J. H. Barbi, J. D. Sutton, H. C. Kirby, and J. France. 2001b. The effect of energy supplementation on nitrogen utilization in lactating dairy cows fed grass silage diets. J. Anim. Sci. 79:240-246.

Cochran, R. C., D. C. Adams, J. D. Wallace, and M. L. Galyean. 1986. Predicting digestibility of different diets with internal markers: Evaluation of four potential markers. J. Anim. Sci. 63:1476-1487.

Dhiman, T. R., and L. D. Satter. 1997. Yield response of dairy cows fed different proportions of alfalfa silage and corn silage. J. Dairy Sci. 80:2069-2082.

Gaynor, P. J., D. R. Waldo, A. V. Capuco, R. A. Erdman, L. W. Douglass, and B. B. Teter. 1995. Milk fat depression, the glucogenic theory, and trans-C18:1 fatty acids. J. Dairy Sci. 78:2008-2015.

Grant, R. J., and D. R. Mertens. 1992. Influence of buffer $\mathrm{pH}$ and raw corn starch addition on in vivo fiber digestion kinetics. J. Dairy Sci. 75:2765-2768.

Griinari, J. M., D. A. Dwyer, M. A. McGuire, D. E. Bauman, D. L. Palmquist, and K. V. V. Nurmela. 1998. Trans-octadecenoic acids and milk fat depression in lactating dairy cows. J. Dairy Sci. $81: 1251-1261$.

Gustafsson, A. H., and D. L. Palmquist. 1993. Diurnal variation of rumen ammonia, serum urea, and milk urea in dairy cows at high and low yields. J. Dairy Sci. 76:475-484.

Hintz, R. W., D. R. Mertens, and K. A. Albrecht. 1995. Effects of sodium sulfite on recovery and composition of detergent fiber and lignin. J. AOAC 78:16-22.

Hristov, A. N., and G. A. Broderick. 1996. Synthesis of microbial protein in ruminally cannulated cows fed alfalfa silage, alfalfa hay, or corn silage. J. Dairy Sci. 79:1627-1637.

Huhtanen, P., K. Kaustell, and S. Jaakkola. 1994. The use of internal markers to predict total digestibility and duodenal flow of nutrients in cattle given six different diets. Anim. Feed Sci. Technol. 48:211-227.

Kalscheur, K. F., B. B. Teter, L. S. Piperova, and R. D. Erdman. 1997. Effect of dietary forage concentration and buffer addition on duodenal flow of trans-C18:1 fatty acids and milk fat production in dairy cows. J. Dairy Sci. 80:2104-2114.

Krause, M. K., and D. K. Combs. 2003. Effects of forage particle size, forage source, and grain fermentability on performance and ruminal pH in midlactation cows. J. Dairy Sci. 86:1382-1397.

Luchini, N. D., G. A. Broderick, R. E. Muck, N. F. Makoni, and R. L. Vetter. 1997. Effect of storage system and dry matter content on the composition of alfalfa silage. J. Dairy Sci. 80:1827-1832.

Muck, R. E. 1987. Dry matter level effects on alfalfa silage quality. 1. Nitrogen transformations. Trans. ASAE 30:7-14.

Muck, R. E., D. R. Mertens, and R. P. Walgenbach. 1996. Proteolysis in Different Forage Silages. ASAE Paper No. 961031, American Society of Agricultural Engineers, St. Joseph, MI.

Nousiainen, J., K. J. Shingfield, and P. Huhtanen. 2004. Evaluation of milk urea nitrogen as a diagnostic of protein feeding. J. Dairy Sci. 87:386-398.

NRC. 2001. Nutrient Requirements of Dairy Cattle. 6th rev. ed. Natl. Acad. Sci., Washington, DC.

Oba, M., and M. S. Allen. 1999. Evaluation of the importance of the digestibility of neutral detergent fiber from forage: Effects on dry matter intake and milk yield of dairy cows. J. Dairy Sci. 82:589-596.

Olmos Colmenero, J. J., and G. A. Broderick. 2006. Effect of dietary crude protein concentration on milk production and nitrogen utilization in lactating dairy cows. J. Dairy Sci. 89:1704-1712. 
Onetti, S. G., R. D. Shaver, M. A. McGuire, and R. R. Grummer. 2001. Effect of type and level of dietary fat on rumen fermentation and performance of dairy cows fed corn silage-based diets. J. Dairy Sci. 84:2751-2759.

Onetti, S. G., R. D. Shaver, M. A. McGuire, D. L. Palmquist, and R. R. Grummer. 2002. Effect of supplemental tallow on performance of dairy cows fed diets with different corn silage:alfalfa silage ratios. J. Dairy Sci. 85:632-641.

Onetti, S. G., S. M. Reynal, and R. R. Grummer. 2004. Effect of alfalfa forage preservation method and particle length on performance of dairy cows fed corn silage-based diets and tallow. J. Dairy Sci. 87:652-664.

Oser, B. L. 1965. Hawk's Physiological Chemistry. 14 ed. McGrawHill, New York, NY.

Reynal, S. M., and G. A. Broderick. 2005. Effect of dietary level of rumen-degraded protein on production and nitrogen metabolism in lactating dairy cows. J. Dairy Sci. 88:4045-4064.

Ruppert, L. D., J. K. Drackley, D. R. Bremmer, and J. H. Clark. 2003. Effects of tallow in diets based on corn silage or alfalfa silage on digestion and nutrient use by lactating dairy cows. J. Dairy Sci. 86:593-609.

Santos, H. H. B. 2003. Effects of forage source and dietary protein content on milk production and $\mathrm{N}$ utilization by lactating cows. Master's Thesis, University of Wisconsin-Madison, Madison.
SAS Institute. 1999-2000. SAS/STAT User's Guide. Release 8.1. SAS Institute, Inc., Cary, NC.

Shahani, K. M., and H. H. Sommer. 1951. The protein and nonprotein nitrogen fractions in milk. I. Methods of Analysis. J. Dairy Sci. 34:1003-1009.

Valadares, R. F. D., G. A. Broderick, S. C. Valadares Filho, and M. K. Clayton. 1999. Effect of replacing alfalfa silage with high moisture corn on ruminal protein synthesis estimated from excretion of total purine derivatives. J. Dairy Sci. 82:2686-2696.

Van Soest, P. J., J. B. Robertson, and B. A. Lewis. 1991. Methods for dietary fiber, neutral detergent fiber, and nonstarch polysaccharides in relation to animal nutrition. J. Dairy Sci. 74:35833597.

Vogels, G. D., and C. van der Grift. 1970. Differential analyses of glyoxylate derivatives. Anal. Biochem. 33:143-157.

Wattiaux, M. A., and K. L. Karg. 2004a. Protein level for alfalfa and corn silage-based diets: I. Lactational response and milk urea nitrogen. J. Dairy Sci. 87:3480-3491.

Wattiaux, M. A., and K. L. Karg. 2004b. Protein level for alfalfa and corn silage-based diets: II. Nitrogen balance and manure characteristics. J. Dairy Sci. 87:3492-3502.

Wiersma, D. W., P. R. Carter, K. A. Albrecht, and J. G. Coors. 1993. Kernel milkline stage and corn forage yield, quality, and dry matter content. J. Prod. Agric. 6:94-99. 